\title{
Hydroalcoholic extract of leaves of Arrabidaea brachypoda (DC.) Bureau present antispasmodic activity mediated through calcium influx blockage
}

Fabio de Souza Monteiro ${ }^{1 *}$ (D), Jhone Robson da Silva Costa ${ }^{1}$ (D), Lenivaldo Jorge Alves Martins ${ }^{2}$ (D), Cláudia Quintino da Rocha ${ }^{2}$ (D), Antonio Carlos Romao Borges ${ }^{1}$ (i), Marilene Oliveira da Rocha Borges ${ }^{1}$ (1)

'Laboratory of Research and Graduate in Pharmacology, Federal University of Maranhão (UFMA), São Luis, MA, Brasil ${ }^{2}$ Laboratory of Advanced Phytomedicine Studies, Federal University of Maranhão (UFMA), São Luis, MA, Brasil

*Corresponding author: fabio.souza@ufma.br

\begin{abstract}
Aim: Since other species of the Bignoniaceae Family presented of antispasmodic activity, it was decided, by chemotaxonomic criterion, to determine the antispasmodic activity of the leaves of Arrabidaea brachypoda. Methodology: the segments of the rat jejunum were suspended in glass vats containing specific saline solution, at an appropriate temperature, and after stabilization period, were stimulated by a contractile agent to observe the inhibitory or relaxing effect of EHFAB. Results: EH-FAB showed the presence of 10 compounds, mainly rutin and it has an antispasmodic activity as it inhibits the phasic component and relaxes the tonic component of the contraction in isolated rat jejunum. To assess the mechanism of antispasmodic action, cumulative curves to the CCh were performed in which a non-competitive antagonism was observed, due to a displacement of the control curve to the right and reduction of the maximum contraction effect $\left(E_{\max }\right)$. Afterward, the participation of the calcium and/or potassium channels was evaluated by increasing the extracellular potassium, and it was observed that the EH-FAB relaxed the rat jejunum, suggesting the participation of the $\mathrm{Ca}^{2+}$ channels. To corroborate that hypothesis, the EH-FAB was tested against cumulative curves to $\mathrm{Ca}^{2+}$ in a free depolarizing solution of $\mathrm{Ca}^{2+}$, and it was observed that there was a shift of the curve to the right with a reduction in $\mathrm{E}_{\max }$. Conclusions: EH-FAB presents antispasmodic activity in isolated rat jejunum and it is suggested to block the influx of $\mathrm{Ca}^{2+}$ through voltage-gated calcium channels, signaling the therapeutic potential for the treatment of colic and/or diarrhea.
\end{abstract}

Keywords: Medicinal Pant. Bignoniaceae. Smooth Muscle. Leaf. Bowel. Rattus norvegicus.

\section{How to cite}

Monteiro FS, Costa JRS, Martins LJA, Rocha CQ, Borges ACR, Borges MOR. Hydroalcoholic extract of leaves of Arrabidaea brachypoda (DC.) Bureau present antispasmodic activity mediated through calcium influx blockage. Rev Ciênc Farm Básica Apl. 2020;41:e667.

https://doi.org/10.4322/2179-443X.0667

\section{INTRODUCTION}

Arrabidaea brachypoda (DC) Bureau (synonym: Fridericia platyphylla (Cham.) LG Lohmann), belonging to the Bignoniaceae Family and to the genus Arrabidaea, it is a native bush of the Brazilian Cerrado, with 1.0-2.0 m height, popularly known as "cervejinha do campo", and used in the southeast and northeast of Brazil for the treatment of kidney stones and painful joints 
(arthritis). This species has been studied from a chemical and pharmacological point of view (Yanagizawa \& Maimoni-Rodella, 2007; Rocha et al., 2011 and 2014; Rodrigues et al., 2017; Serpeloni et al., 2020; Bertanha et al., 2020).

For example, the leaves of $A$. brachypoda showed the presence of flavonoids (cirsimaritine, cirsiliol, hispidulin and 3 ', 4'-dihydroxy-5,6,7-trimethoxyflavone) with antifungal activity (Alcerito et al., 2002; Patel \& Patel, 2017); flavonols (arrabidoside A and B, rutin and isoquercitrin) with antioxidant, analgesic and anti-inflammatory potential (Garcia, 2008; Da Rocha, 2010, 2013), among other things. In addition, the literature highlights the obtaining of some patents with this species (Da Rocha et al., 2015a, b, c).

The pharmacological study of plants constitutes a field of new scientific knowledge and generators of wealth. In addition, it interests the Ministry of Health, as well as the National Health Surveillance Agency ("ANVISA"), to collect pharmacological information about the plants used in Brazil (Balbino \& Dias, 2010; De Figueredo et al., 2014; Souza et al., 2016).

In order to contribute to the evaluation of the pharmacological potential of plants in Brazil and to propose new herbal medicines for popular uses with efficacy and safety (Resende et al., 2017), this study aimed to determine the antispasmodic activity of A. brachypoda, because, by the chemotaxonomic criterion, it was observed that other species of the Bignoniaceae presented this activity (Gharib et al., 2007; Cavalcante et al., 2008, 2010). In addition, typical plants of the Brazilian Cerrado, such as those of the genus Arrabidaea, are known to be valuable sources of bioactive compounds (Castro et al., 1999).

The antispasmodic activity is related to the ability of certain medications (extracts of plants, fractions, or isolated substances) to prevent or interrupt the painful and involuntary contraction (spasm) of the intestinal smooth muscle (Forster et al., 1980; Hani, 2014; Har \& Croffie, 2017; Monteiro et al., 2018). To study that activity and its likely mechanism of action in intestinal smooth muscle, segments of isolated jejunum from rats can be used.

The preparation of isolated tissues is easy to handle and the presence or absence of the antispasmodic effect can be fully assessed. Smooth muscle is present in several hollow organs in the body systems of animals and humans controlling various physiological processes, such as intestinal peristalsis, among other things, whose deregulations are implicated in diseases such as, dysentery and intestinal colic (Webb, 2003; Kim et al., 2008; Sweeney \& Hammers, 2018; Monteiro et al., 2020).

Thus, this work aims to contribute to the pharmacology of the Bignoniaceae family and as an alternative for obtaining herbal medicines accessible to the neediest population (Brandão et al., 2006; Shakya, 2016; Jamshidi-Kia et al., 2018). Therefore, the investigation of plants with antispasmodic activity is essential from a socio-economic point of view, and the investigation of the mechanism of action is one of the most interesting points of Pharmacology and may guide research in order to obtain drugs safely and effectively.

\section{MATERIAL AND METHODS}

\subsection{Material}

\subsubsection{Botanical material}

Samples of A. brachypoda leaves were collected in April 2016 at Sant'Ana da Serra farm in

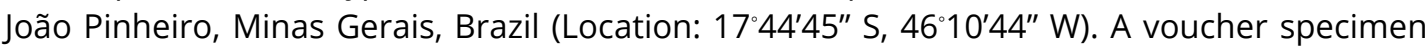
$\left(N^{\circ} .17935\right)$ was deposited at the Herbarium of the Federal University of Ouro Preto, Minas Gerais, Brazil. The plant was collected according to Brazilian laws concerning the protection of biodiversity (SISGEN n A451DE4). 


\subsubsection{Animals}

Rats of the species Rattus norvegicus were used, Wistar lineage, adults, male, healthy at the clinical examination, approximately 80 days old ( $250-350 \mathrm{~g})$, provided by Central Biotery of UFMA. The animals were kept in polyethylene cages, lined with xylan, with food and water ad libitum and under a 12-hour light / dark cycle, at a temperature of $22^{\circ} \mathrm{C}$. All procedures described in the present study were approved by the Animal Research Ethics Committee of UFMA, Brazil (process No. 23115.004440/2017-09).

\subsubsection{Devices and drugs}

kymographs whose cylinders are used to register phasic contractions, using frontal registration isotonic levers (DTF, Brazil). Sensitive Isometric Transducer (Model n: MLT0202, ADInstruments, Inc., Colorado Springs, CO) for measuring tension ( 0.0 and $25.0 \mathrm{~g}$ ) coupled to Power Lab 8/35 data acquisition system (Model No PL3508/P, ADInstruments Pty Ltd, Castle Hill, Australia) which was connected to a computer. The drugs used to generate contractions were purchased from SigmaAldrich (St. Louis, MO, USA): Carbamylcholine chloride (Carbachol or $\mathrm{CCh}$ ); Potassium chloride $(\mathrm{KCl})$; Calcium chloride $\left(\mathrm{CaCl}_{2}\right)$. All buffer salts were purchased from Vetec (Rio de Janeiro, RJ, Brazil): Normal Tyrode's Solution (mM): $\mathrm{NaCl}$ (135.0); $\mathrm{KCl}(5.0)$; $\mathrm{CaCl}_{2}$ (2.0); $\mathrm{MgCl}_{2}$ (1.0); $\mathrm{NaHCO}_{3}$ (15.0); $\mathrm{NaH}_{2} \mathrm{PO}_{4}$ (1.0); Glucose (11.1) (Udia et al., 2009). Depolarizing Tyrode's Solution (KCl, $70 \mathrm{mM}$; $\mathrm{Ca}^{2+}$-free): (mM): $\mathrm{NaCl}(65.0) ; \mathrm{KCl}(70.0) ; \mathrm{CaCl}_{2}(2.0)$; $\mathrm{MgCl}_{2}$ (1.0); $\mathrm{NaHCO}_{3}$ (15.0); $\mathrm{NaH}_{2} \mathrm{PO}_{4}$ (1.0); Glucose (11.1).

\subsection{Method}

\subsubsection{Preparation of crude extract}

The leaves were dried in an oven-controlled temperature of $60^{\circ} \mathrm{C}$, then they were crushed with a knife mill equipped with mechanical stirring to obtain a fine powder $(1.5 \mathrm{~kg})$. The extraction was performed by means of exhaustive percolation using $70 \% \mathrm{v} / \mathrm{v}$ ethyl alcohol. After extraction, the evaporation of the solvent was carried out in a rotary evaporator with reduced pressure and maximum temperature of $40^{\circ} \mathrm{C}$, and later lyophilized, obtaining about $20 \mathrm{~g}$ (yield of approximately 1.3\%) of a concentrated hydroalcoholic extract, which was called EH-FAB (Da Rocha, 2013). This was solubilized in distilled water to a concentration of $10 \mathrm{mg} / \mathrm{mL}$ (stock solution), preserved at $0{ }^{\circ} \mathrm{C}$ and diluted in distilled water according to the need for each experimental protocol in the day of the experiment. EH-FAB concentrations were used in multiples of three, with the maximum concentration being $729 \mu \mathrm{g} / \mathrm{mL}$ since it is the maximum concentration used in experiments with isolated organs. When the observed effect was larger than $50 \%$ at $729 \mu \mathrm{g} / \mathrm{mL}$, it was sought the concentration that would provide a $0 \%$ effect (Monteiro et al., 2018, 2020).

\subsubsection{Analysis of hydroalcoholic extract of leaves of Arrabidaea brachypoda by FIA-ESI-IT-MS}

The hydroalcoholic extract of Arrabidaea brachypoda was analyzed by a mass spectrometer LCQ Fleet, Thermo Scientific, equipped with apparatus for direct insertion of sample by flow injection analysis (FIA). The sample's ionization was made by electrospray (ESI) and the fragmentations in multiple stage $\left(M^{n}\right)$ were performed in ion-trap (IT). Negative mode was used for analysis of first order and multiple stage mass spectra. Analysis conditions: capillary voltage of $-4 \mathrm{~V}$ and $-5 \mathrm{kV}$ for spray, capillary temperature of $280^{\circ} \mathrm{C}$, carrier gas $\left(\mathrm{N}_{2}\right)$ with flow of 60 units. Acquisition range of $\mathrm{m} / \mathrm{z}$ 50-1000, with two or more events scans performed simultaneously in MS LCQ. The first event was a complete scan (full-scan) to get ions in acquisition range. Other events were the $\mathrm{MS}^{\mathrm{n}}$ experiment with collision induced dissociation energy between 20 and 35 . The software Xcalibur software was used (Thermo Scientific ${ }^{\circledR}$ ) for acquisition and data processing. 


\subsubsection{Investigation of the effect of EH-FAB in isolated rat jejunum}

All rats were euthanized with $\mathrm{CO}_{2}$ gas following the principles of laboratory animal care based on the guidelines of the bioethics committee. The jejunum was isolated from rats that remained fasting for $18 \mathrm{~h}$, with water at will. The isolated tissues were cleaned, under a Petri dish containing adequate nutrient solution and aerated with oxygen. After removing the fat, the tissue was sectioned $(1.5 \mathrm{~cm})$ and suspended in glass vats $(05$ or $10 \mathrm{~mL}$ ) containing physiological solution, maintained at $37^{\circ} \mathrm{C}$. According to each experimental protocol, the jejunum tissue remained under tension $(1 \mathrm{~g}$ ) for 30 or $60 \mathrm{~min}$, with intervals of $15 \mathrm{~min}$ of washing with nutrient solution to avoid the interference of metabolites (Altura \& Altura, 1970; Brito et al., 2018).

After the initial procedures, as described above, the jejunum segment is tensioned ( $30 \mathrm{~min}$ ) by means of a frontal registration lever on a kymograph cylinder to assess the phase component of the contraction. Posteriorly, two curves of similar amplitudes were induced by carbachol (CCh) $10^{-6} \mathrm{M}$ in rat jejunum. In the presence of different concentrations of the EH$F A B$ extract, a third contraction was induced to assess the inhibitory effect. The concentration of EH-FAB that produced the maximum inhibitory effect $\left(E_{\max }\right)$ was expressed as mean \pm S.E.M. In another experiment, the jejunum segment is tensioned $(60 \mathrm{~min}$ ) through force transducers assess the tonic component of contraction. Posteriorly, the tissue of rat jejunum was contracted by CCh $10^{-6} \mathrm{M}$ and when a stable contraction was attained (15-20 min), EH-FAB was cumulatively added. The relaxing effect induced by EH-FAB was expressed as the reverse percentage of the initial contraction force elicited by the agonist. The concentration of EH-FAB that produced the maximum relaxing effect $\left(E_{\max }\right)$ was expressed as mean \pm S.E.M. (Monteiro et al., 2018).

\subsubsection{Investigation of the antispasmodic mechanism of action of the EH-FAB}

\subsubsection{Determination of the type of antagonism of EH-FAB in isolated rat jejunum}

The jejunum was set up as described in item 2.2.2. The responses were recorded on a Kymograph paper through an isotonic frontal writing lever. After the stabilization during 30 min, two cumulative concentration-response curves were obtained by cumulatively adding $\mathrm{CCh}\left(10^{-9}\right.$ up until $\left.3 \times 10^{-5} \mathrm{M}\right)$ in rat jejunum; then, in the absence of CCh, the EH-FAB $(27,81,243$ and $729 \mu \mathrm{g} / \mathrm{mL})$ was incubated for $15 \mathrm{~min}$ in different tests and preparations. After that time, a new cumulative CCh response curve was displayed in the presence of the EH-FAB. The type of antagonism was evaluated by comparing the values of $E_{\max }$ of contraction in the absence (control) and in the presence of EH-FAB (Van Rossum, 1963; Ali et al., 2020).

\subsubsection{Evaluation of the participation of calcium or potassium channels of EH-FAB in isolated rat jejunum}

The initial procedures were described in item 2.2.2. Posteriorly, the tissue of rat jejunum was contracted by $\mathrm{KCl} 75 \mathrm{mM}$ and when a stable contraction was attained (15-20 min), EH-FAB was cumulatively added. The relaxing effect induced by EH-FAB was expressed as the reverse percentage of the initial contraction force elicited by the spasmogenic agent. The $E_{\max }$ of relaxation was expressed as mean \pm S.E.M. (Hamilton \& Weston, 1989).

In another experiment, the following experimental protocol was performed: the jejunum was mounted as described in item 2.2.2. The responses and the profile of the experimental protocol were recorded as described in item 2.2.3.1. After, the external calcium of the normal Tyrode's solution was eliminated with depolarizing Tyrode's solution ( $\mathrm{KCl}, 70 \mathrm{mM} ; \mathrm{Ca}^{2+}$-free). Two cumulative concentration-response curves of $\mathrm{Ca}^{2+}$ were obtained by cumulatively adding $\mathrm{CaCl}_{2}\left(3 \times 10^{-8}\right.$ up until $\left.3 \times 10^{-5} \mathrm{M}\right)$ in the absence and presence of EH-FAB $(27,81$ and $243 \mu \mathrm{g} / \mathrm{mL}$ ), which were added to the bath $10 \mathrm{~min}$ before the addition of $\mathrm{Ca}^{2+}$. This curve was compared with those obtained in the absence of $\mathrm{EH}-\mathrm{FAB}$ and the results were expressed as a percentage of the maximal response to $\mathrm{CaCl}_{2}$ alone (Van Rossum, 1963; Ali et al., 2020). 


\subsubsection{Statistical analysis}

All the results obtained were expressed as a percentage of the mean \pm standard error of the mean (S.E.M.) and analyzed statistically using the "t" test or analysis of variance (ANOVA) "one-way" followed by the Bonferroni test, where $P$ values less than 0.05 were considered significant. The values of $E_{\max }$ were calculated by non-linear regression for all experiments performed (Jenkinson et al., 1995; Arifin \& Zahiruddin, 2017). All data were analyzed using the Graphpad Prism' program version 5.01 (Graphpad Software Inc., San Diego CA, USA).

\section{RESULTS}

\subsection{Chemical characterization of EH-FAB}

The chemical characterization of EH-FAB, obtained by FIA-ESI-IT/MS showed the presence of important metabolites, such as flavonoids. It was possible to identify 10 of these components, mainly rutin (Figure 1 and Table 1).

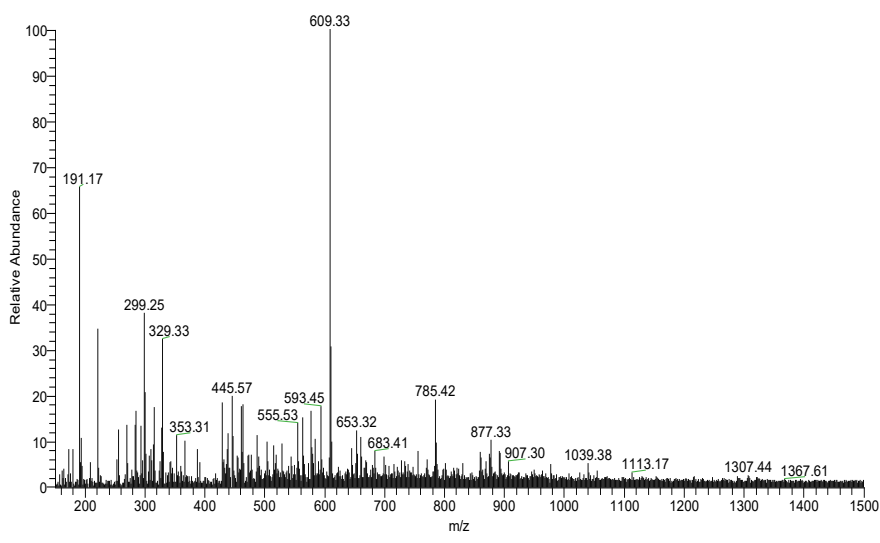

Fig. 1: Typical direct flow injection analysis FIA-ESI-IT-MS fingerprint spectra obtained in negative ion mode of the $70 \%$ EtOH from the leaves of Arrabidaea brachypoda.

Table 1. Identification of compounds in Arrabidaea brachypoda by FIA-ESI-IT / MS

\begin{tabular}{|c|c|c|c|}
\hline Compound & $\begin{array}{l}\text { Fórmula molecular } \\
\text { (Weigth Molecular) }\end{array}$ & {$[\mathrm{M}-\mathrm{H}]^{-}$} & MS $^{n}$ \\
\hline Apigenin & $\mathrm{C}_{15} \mathrm{H}_{10} \mathrm{O}_{5}(270)$ & 269 & $151=[\mathrm{M}-1118-\mathrm{H}]^{-}$ \\
\hline Luteolin & $\mathrm{C}_{15} \mathrm{H}_{10} \mathrm{O}_{6}(286)$ & 285 & $267=[\mathrm{M}-18-\mathrm{H}]^{-}, 243=[\mathrm{M}-42-\mathrm{H}]^{-}$ \\
\hline Hispidulin & $\mathrm{C}_{16} \mathrm{H}_{12} \mathrm{O}_{6}(300)$ & 299 & $284=[\mathrm{M}-15-\mathrm{H}]^{-}, 117=[\mathrm{M}-15-167-\mathrm{H}]^{-}$ \\
\hline Cirsiliol & $\mathrm{C}_{17} \mathrm{H}_{14} \mathrm{O}_{7}(330)$ & 329 & $314=[M-15-H]^{-}$ \\
\hline 7-metoxipigenina-6-C-hexose & $\mathrm{C}_{22} \mathrm{H}_{22} \mathrm{O}_{10}(446)$ & 445 & $401=[\mathrm{M}-44-\mathrm{H}] ;, 269=[\mathrm{M}-132-\mathrm{H}]$. \\
\hline 7-methoxyluteolin-6-C-hexose & $\mathrm{C}_{22} \mathrm{H}_{22} \mathrm{O}_{11}(462)$ & 461 & $\begin{array}{l}443=[\mathrm{M}-18-\mathrm{H}]^{\prime}, 371=[\mathrm{M}-90-\mathrm{H}]^{-3} 341=[\mathrm{M}-120- \\
\mathrm{H}]^{-313}=[\mathrm{M}-120-28-\mathrm{H}]^{\prime}, 298=[\mathrm{M}-120-28-15-\mathrm{H}]^{-}\end{array}$ \\
\hline Isoquercitrin & $\mathrm{C}_{21} \mathrm{H}_{20} \mathrm{O}_{12}(464)$ & 463 & $445=[M-132-H]^{-}, 301=[M-132-H]^{-}$ \\
\hline $\begin{array}{l}\text { Apigenin-6-C-hexose, 8-C- } \\
\text { hexose }\end{array}$ & $\mathrm{C}_{27} \mathrm{H}_{30} \mathrm{O}_{15}(594)$ & 593 & $\begin{array}{c}575=[\mathrm{M}-18-\mathrm{H}]^{-}, 503=[\mathrm{M}-90-\mathrm{H}]^{\prime}, 473=[\mathrm{M}-120- \\
\mathrm{H}]^{-}, 383=[\mathrm{M}-120-90-\mathrm{H}]^{-}, 485=[\mathrm{M}-90-18-\mathrm{H}]^{-}\end{array}$ \\
\hline Rutin & $\mathrm{C}_{27} \mathrm{H}_{30} \mathrm{O}_{16}(610)$ & 609 & $463=[\mathrm{M}-146-\mathrm{H}]^{-}, 301=[\mathrm{M}-146-162-\mathrm{H}]^{-}$ \\
\hline Arrabidoside A & $\mathrm{C}_{37} \mathrm{H}_{40} \mathrm{O}_{19}(786)$ & 785 & $609=[\mathrm{M}-176-\mathrm{H}]^{-}, 301=[\mathrm{M}-308-\mathrm{H}]^{-}$ \\
\hline
\end{tabular}

\subsection{Investigation of the effect of EH-FAB in isolated rat jejunum}

EH-FAB inhibit phasic contractions induced by $C C h 10^{-6} \mathrm{M}\left(\mathrm{E}_{\max }=100 \%\right)$ in isolated rat jejunum (Figure 2). In addition, EH-FAB relax rat jejunum pre-contracted by $\mathrm{CCh} 10^{-6} \mathrm{M}$ of manner concentration-dependent $\left(E_{\max }=90.8 \pm 5.7 \%\right.$ ) (Figure 3). 


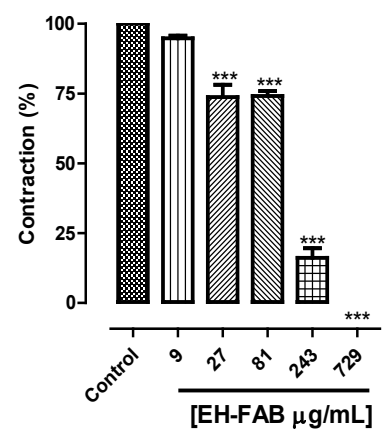

Fig. 2. Effect of EH-FAB against phasic contractions induced by $C C h 10^{-6} \mathrm{M}$ in isolated rat jejunum. The vertical columns and bars represent the mean and standard error of the mean of three experiments, respectively. Oneway ANOVA followed by Bonferroni's post-test, $* \star \star ~ p<0.001$ (control vs. EH-FAB), $(n=4)$.

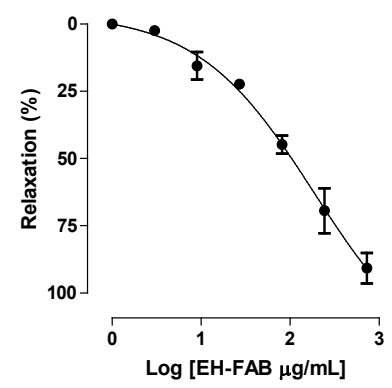

Fig. 3. Effect of EH-FAB against tonic contractions induced by $\mathrm{CCh} 10^{-6} \mathrm{M}$ in isolated rat jejunum. The symbols and vertical bars represent the percentage of the average and the e.p.m., respectively, $(n=3)$.

\subsection{Investigation of the antispasmodic mechanism of action of the EH-FAB}

\subsubsection{Determination of the type of antagonism of EH-FAB in isolated rat jejunum}

EH-FAB $(27,81,243$ and $729 \mu \mathrm{g} / \mathrm{mL})$ antagonized the cumulative concentration-response curves to $\mathrm{CCh}\left(10^{-9}\right.$ to $\left.3 \times 10^{-5} \mathrm{M}\right)$, shifting it to the right and reducing $\mathrm{E}_{\max }(100 \%)$ of the CCh to $80.2 \pm 6.9 ; 62.9 \pm 9.8 ; 19.9 \pm 4.8$ and $3.0 \pm 1.4 \%$ (Figure 4).

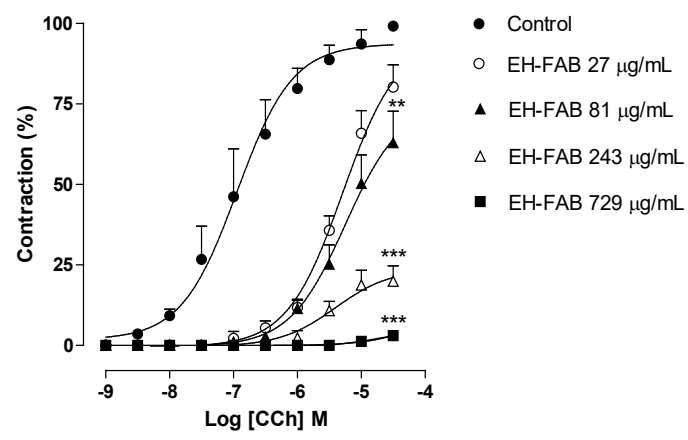

Fig. 4. Effect of EH-FAB against cumulative CCh contractions in isolated rat jejunum. The symbols represent the mean and standard error of the mean, respectively. One-way ANOVA followed by the Bonferroni post-test, ** $p<0.01$ and $* * * p<0.001$, $(\mathrm{n}=5)$. 


\subsubsection{Evaluation of the participation of calcium or potassium channels of EH-FAB in isolated rat jejunum}

EH-FAB $(1,3,9,27,81,243$ and $729 \mu \mathrm{g} / \mathrm{mL})$ relaxes the rat jejunum pre-contracted by $\mathrm{KCl}$ $75 \mathrm{mM}$ in a concentration-dependent manner $\left(\mathrm{E}_{\max }=82.5 \pm 3.8 \%\right.$ ) (Figure 5). In addition, EH$\operatorname{FAB}(27,81,243$ and $729 \mu \mathrm{g} / \mathrm{mL})$ antagonized the cumulative concentration-response curves to $\mathrm{CaCl}_{2}\left(3 \times 10^{-8}\right.$ to $\left.3 \times 10^{-5} \mathrm{M}\right)$, shifting it to the right and with a reduction in the $\mathrm{E}_{\max }(100 \%)$ of the CCh to $80.2 \pm 6.9 ; 62.9 \pm 9.8 ; 19.9 \pm 4.8$ and $3.0 \pm 1.4 \%$ (Figure 6).

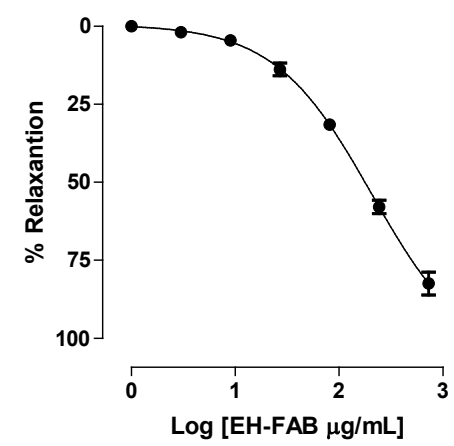

Fig. 5. Effect of EH-FAB against tonic contractions induced by $\mathrm{KCl} 75 \mathrm{mM}$ in isolated rat jejunum. The symbols and vertical bars represent the percentage of the average and the e.p.m., respectively; $(n=3)$.

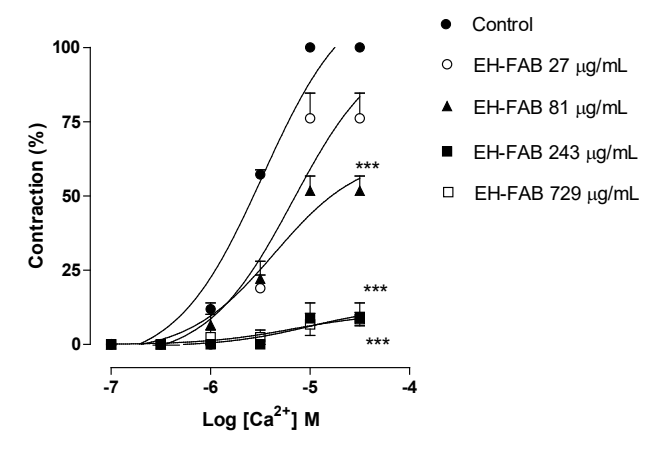

Fig. 6. Effect of EH-FAB on isolated rat jejunum contractile response to $\mathrm{CaCl}_{2}$. Symbols and vertical lines indicate means \pm SEM, respectively. One-way ANOVA followed by Bonferroni's test (Control vs EHF-SC),

$$
\star * \star p<0.001 ;(\mathrm{n}=3) \text {. }
$$

\section{DISCUSSION}

The chemical and pharmacological study of the hydroalcoholic extract of the species Arrabidaea brachypoda (EH-FAB) is presented in this study. Chemical characterization is important to know which secondary metabolites are present in a given species since chemical compounds can undergo quantitative or qualitative variations influenced by the main factors: environmental, ontogenetic, and hereditary (Kyriacou et al., 2019).

Therefore, it was possible to demonstrate that the EH-FAB showed the presence mainly of flavonoids (Figure 1 and Table 1). Although the role of secondary metabolites is to defend the plant, they are extremely important for human health. Flavonoids, for example, can play an important role in preventing gastrointestinal disorders such as diarrhea and colic (Oteiza et al., 2018). In addition, many medicinal plants containing flavonoids show antispasmodic activity (Sadraei et al., 2018).

The antispasmodic activity can be investigated through simple experiments using isolated tissues of intestinal smooth muscle such as rat jejunum. In addition, it is possible to investigate 
the mechanism of action antispasmodic at a functional level. The contraction in the smooth muscle of the intestine in response to various agents is often composed of two phases: phasic, fast, and unsustainable component followed by a tonic, slow, and sustained component. The mechanism responsible for the phasic component is related to the activation of a metabotropic receptor coupled to protein G. On the other hand, the tonic component is mainly mediated by calcium influx through voltage-dependent calcium channels ( $\mathrm{Ca}_{v}$ ) (Bolton, 1979; van Breemen \& Saida, 1989; Murthy, 2006; Sakamoto et al., 2007; Qin et al., 2017).

It was observed that EH-FAB has an effect on both phasic and tonic component of CCh-induced contraction, in other words, it inhibited contraction and relaxed the isolated rat jejunum, respectively, in a significant and concentration-dependent manner (Figures 2 and 3 ). In the literature, it is observed that atropine, have antispasmodic activity because they inhibit competitively muscarinic metabotropic $M_{3}$ type receptors (Melchiorre et al., 1987; Montgomery et al., 2016).

In isolated rat jejunum the $M_{3}$ type metabotropic receptors are primarily responsible for the component phasic of the contraction (Suguro et al., 2010). Then the following came up question: would the EH-FAB be acting by competitive antagonism in isolated rat jejunum? To answer this question, it was decided to investigate which type of antagonism the EH-FAB acts. The result shows, at a functional level, non-competitive antagonism (Figure 4).

The non-competitive antagonism can be explained by the blocking of $\mathrm{Ca}_{v}$ or by activating the potassium channels, which are present in the plasma membrane of intestinal smooth muscle. The activation of the $\mathrm{Ca}_{v}$ is responsible for the sustained tonic component of the contraction, while the regulation of the contractile process is performed through the activation of the potassium channels (Bolton et al., 1981; Thorneloe \& Nelson 2005; Mehmood et al., 2015).

The evaluation of the participation of the $\mathrm{Ca}_{v}$ or the potassium channel in the relaxing action mechanism of the EH-FAB can be done by analyzing Figure 5, where, it can be seen that the EH-FAB significantly relaxes the rat jejunum when pre-contracted by high concentrations of extracellular potassium (electromechanical coupling). As the main mechanism by which $\mathrm{KCl}$ induces contraction is the opening of the $\mathrm{Ca}_{v}$ by depolarization of the membrane (Long et al., 2005; Ratz et al., 2005; Hou et al., 2020), the Ca $a_{V}$ block hypothesis is accepted to explain the mechanism of action of EH-FAB in rat jejunum. To corroborate this hypothesis, Figure 6 shows that the $\mathrm{EH}-\mathrm{FAB}$ shifts the $\mathrm{CaCl}_{2}$ curve to the right, with a reduction in the maximum effect, characteristic of $\mathrm{Ca}_{v}$ inhibition of calcium influx.

The same suggestion of blocking calcium influx through the $\mathrm{Ca}_{v}$ was observed with Arrabidaea chica in the smooth muscle of arteries (Cartagenes et al., 2014). In addition, the effect reported for $A$. chica and now A. brachypoda may be due to the flavonoids present in the phytochemical composition of these two species (Takemura et al., 1995; Alcerito et al., 2002; Siraichi et al., 2013), since the literature shows some plants with flavonoids promoting the blockage of $\mathrm{Ca}^{2+}$ influx by $\mathrm{Ca}_{v}$ (Ghayur et al., 2006; Chen et al., 2009; Carvalho Correia et al., 2013; Basir, 2017; Patel \& Patel, 2017).

The present study investigated the effect of the hydroalcoholic extract of the leaves of $A$. Brachypoda (EH-FAB) on isolated rat jejunum. The results obtained indicate that EH-FAB has antispasmodic activity by inhibiting $\mathrm{Ca}^{2+}$ influx through $\mathrm{Ca}_{\mathrm{v}}$. As a perspective, it will be used the ( \pm )-Bay K8644 agonist to investigate voltage-sensitive calcium channels (Vissiennon et al., 2007; Kumar et al., 2019). Therefore, with the data presented here, a great contribution is made to the pharmacology of the genus Arrabidaea. Although more studies need to be carried out to better characterize the antispasmodic activity presented by EH-FAB, this study contributed to show the potential of crude leaf extract in the development of bioproducts to treat disorders of contractility of the smooth muscle of the intestine.

\section{ACKNOWLEDGEMENTS}

This work was financed by donations from the Federal University of Maranhão and the Foundation for the Support of Research and Scientific and Technological Development of Maranhão (FAPEMA). 


\section{REFERENCES}

Alcerito T, Barbo FE, Negri G, Santos DYAC, Meda Cl, Young MCM, Chávez D, Blatt CTT. Foliar epicuticular wax of Arrabidaea brachypoda: flavonoids and antifungal activity. Biochem Syst Ecol. 2002;30(7):677-83. http://dx.doi.org/10.1016/S0305-1978(01)00149-1.

Ali MZ, Mehmood MH, Saleem M, Gilani AH. The use of Euphorbia hirta L. (Euphorbiaceae) in diarrhea and constipation involves calcium antagonism and cholinergic mechanisms. BMC Complement Med Ther. 2020;20(1):1-16. http://dx.doi.org/10.1186/s12906-019-2793-0. PMid:32020867.

Altura BM, Altura BT. Differential effects of substrate depletion on drug-induced contractions of rabbit aorta. Am J Physiol. 1970;219(6):1698-705. http://dx.doi.org/10.1152/ajplegacy.1970.219.6.1698. PMid:4320911.

Arifin WN, Zahiruddin WM. Sample size calculation in animal studies using resource equation approach. Malays J Med Sci. 2017;24(5):101-5. http://dx.doi.org/10.21315/mjms2017.24.5.11. PMid:29386977.

Balbino EE, Dias MF. Farmacovigilância: um passo em direção ao uso racional de plantas medicinais e fitoterápicos. Rev Bras Farmacogn. 2010;20(6):992-1000. http://dx.doi.org/10.1590/S0102$695 \times 2010005000031$.

Basir SF. Mechanism of flavonoids action in smooth muscle relaxation. World J Pharm Pharm Sci. 2017;6:514-50. http://dx.doi.org/10.20959/wjpps20179-9992.

Bertanha CS, Gimenez VM, Furtado RA, Tavares D, Cunha W, Andrade e Silva M, Januario A, Borges A, Kawano D, Parreira R, Pauletti PM. Isolation, in vitro and in silico Evaluation of Phenylethanoid Glycoside from Arrabidaea brachypoda as Lipoxygenase Inhibitor. J Braz Chem Soc. 2020;31(4):84955. http://dx.doi.org/10.21577/0103-5053.20190248.

Bolton TB, Clark JP, Kitamura K, Lang RJ. Evidence that histamine and carbachol may open the same ion channels in longitudinal smooth muscle of guinea-pig ileum. J Physiol. 1981;320(1):363-79. http://dx.doi.org/10.1113/jphysiol.1981.sp013955. PMid:6275077.

Bolton TB. Mechanisms of action of transmitters and other substances on smooth muscle. Physiol Rev. 1979;59(3):606-718. http://dx.doi.org/10.1152/physrev.1979.59.3.606. PMid:37533.

Brandão MGL, Cosenza GP, Moreira RA, Monte-Mor RLM. Medicinal plants and other botanical products from the Brazilian Official Pharmacopoeia. Rev Bras Farmacogn. 2006;16(3):408-20. http://dx.doi.org/10.1590/S0102-695X2006000300020.

Brito AF, Silva AS, Souza AA, Ferreira PB, Souza ILL, Araujo LCC, Félix GS, Sampaio RS, Silva MCC, Tavares RL, Pereira RA, Miranda M No, Silva BA. Aortic Response to Strength Training and Spirulina platensis Dependent on Nitric Oxide and Antioxidants. Front Physiol. 2018;2018(October):9. http://dx.doi.org/10.3389/fphys.2018.01522.

Cartagenes MS, Lima NF, França LG, Pessoa DLR, Amaral FMM, Abreu IC, Silva SN, Borges MOR, Medeiros IA. Avaliação da atividade anti-hipertensiva do extrato de Arrabidaea chica Verlot em ratos espontaneamente hipertensos. Rev Cienc Salud. 2014;16(2):98-105.

Carvalho Correia AC, Ciberio L, Souza Monteiro F, Oliveira GA, Santos RF, Nascimento RJB, Camara CA, Agra MF, Silva TMS, Silva BA. Aerial parts of Solanum agrarium Sendtn. (Solanaceae) present the flavonoid myricetin 3, 7, 3 trimethyl ether and antispasmodic effect on guinea-pig ileum by blockade of voltage-gated calcium channels. J Med Plant Res [Internet]. 2013 [cited 2020 June 07];7(31): 2293-2299. Available from: https://academicjournals.org/journal/JMPR/articleabstract/AC061FE27899

Castro AAJF, Martins FR, Tamashiro JY, Shepherd GJ. How rich is the flora of Brazilian cerrados? Ann Mo Bot Gard. 1999;86(1):192-224. http://dx.doi.org/10.2307/2666220.

Cavalcante FA, Silva JLV, Carvalho VMN, Camara CA, Silva TMS, Pinto ÂC, Vargas MD, Silva BA. Spasmolytic activity of lapachol and its derivatives, a and $\beta$-lapachone, on the guinea-pig ileum involves blockade of voltage-gated calcium channels. Rev Bras Farmacogn. 2008;18(2):183-9. http://dx.doi.org/10.1590/S0102-695X2008000200007.

Cavalcante FA, Monteiro FDS, Martins IRR, Barbosa TP, Camara CA, Pinto AC, Vargas MD, da Silva BA. Synthetic lapachol derivatives relax guinea-pig ileum by blockade of the voltage-gated calcium channels. Z Naturforsch C. 2010;65(9-10):627-36. http://dx.doi.org/10.1515/znc-2010-9-1016. PMid:21138067. 
Chen G, Zhu L, Liu Y, Zhou Q, Chen H, Yang J. Isoliquiritigenin, a flavonoid from licorice, plays a dual role in regulating gastrointestinal motility in vitro and in vivo. Phytother Res. 2009;23(4):498-506. http://dx.doi.org/10.1002/ptr.2660. PMid:19067384.

Da Rocha CQ. Estudo fitoquímico, avaliação da atividade analgésica e antiinflamatória de extratos e substâncias isoladas de Arrabidaea brachypoda (DC.) Bureau (Bignoniaceae) [dissertação]. Alfenas: UNIFAL; 2010. [cited 2020 June 07]. Available from: https://bdtd.unifalmg.edu.br:8443/handle/tede/390

Da Rocha CQ. Extratos padronizados para o tratamento de doenças crônicas: Arrabidaea spp. [tese]. Araraquara: UNESP; 2013. [cited 2020 June 07]. Available from: https://repositorio.unesp.br/handle/11449/108492

Da Rocha CQ, Vilegas W, Queiroz EF, Wolfender JL, Marcourt L, inventores. Spiandorello FM, procurador. Método de obtenção de compostos a partir de extratos da Arrabidaea brachypoda, compostos e composições farmacêuticas compreendendo os mesmos. BR Patente 102013031925-2 A2. 06 de outubro de 2015a.

Da Rocha CQ, Vilegas W, Queiroz EF, Wolfender JL, Marcourt L. Uso de compostos obtidos a partir de extratos da Arrabidaea brachypoda como antiparasitário. BR patente 102013031927-9 A2. 06 de outubro de $2015 \mathrm{~b}$.

Da Rocha CQ, Vilegas W, Queiroz EF, Wolfender JL, Marcourt L. Uso de compostos obtidos a partir de extratos da Arrabidaea brachypoda como antiulcerogênico. BR patente 102013031926-0 A2. 06 de Outubro de 2015c.

De Figueredo CA, Gurgel IGD, Gurgel GD Jr. A política nacional de plantas medicinais e fitoterápicos: construção, perspectivas e desafios. Physis. 2014;24(2):381-00. http://dx.doi.org/10.1590/S010373312014000200004.

Forster HB, Niklas H, Lutz S. Antispasmodic effects of some medicinal plants. Planta Med. 1980;40(4):309-19. http://dx.doi.org/10.1055/s-2008-1074977. PMid:7220648.

Garcia F. Estudo fitoquímico da fração AcOEt do extrato etanólico das folhas de Arrabidaea brachypoda (DC) Bureau-Bignoniaceae e atividades antioxidante e inibitória da enzima mieloperoxidase das substancias isoladas [dissertação]. Araraquara: UNESP; 2008. [cited 2020 June 07]. Available from: https://repositorio.unesp.br/handle/11449/97989

Gharib NMK, Asadi MM, Bahadoram S. Antispasmodic effect of Tecoma stans (L.) Juss leaf extract on rat ileum. Daru [Internet]. 2007 [cited 2020 June 07];15(3):123-8. Available from: https://www.sid.ir/en/Journal/ViewPaper.aspx?ID=91900

Ghayur MN, Gilani AH, Khan A, Amor EC, Villaseñor IM, Choudhary MI. Presence of calcium antagonist activity explains the use of Syzygium samarangense in diarrhoea. Phytother Res. 2006;20(1):49-52. http://dx.doi.org/10.1002/ptr.1801. PMid:16397921.

Hamilton TC, Weston AH. Cromakalim, nicorandil and pinacidil: novel drugs which open potassium channels in smooth muscle. Gen Pharmacol: The Vascular System. 1989;20(1):1-9. https://doi.org/10.1016/0306-3623(89)90052-9

Hani A. 13. Antiespasmódicos. Acta Gastroenterol Latinoam [Internet]. 2014 [cited 2020 June 07];44(2):57-60. Available from: https://www.redalyc.org/articulo.oa?id=199332762013

Har AF, Croffie JM. Drugs acting on the gut: prokinetics, antispasmodics, laxatives. In Faure C, Thapar N, Di Lorenzo C. Pediatric Neurogastroenterology. Cham: Springer; 2017. p. 469-87. http://dx.doi.org/10.1007/978-3-319-43268-7_44

Hou P, Kang PW, Kongmeneck AD, Yang ND, Liu Y, Shi J, Xu X, White KM, Zaydman MA, Kasimova MA, Seebohm G, Zhong L, Zou X, Tarek M, Cui J. Two-stage electro-mechanical coupling of a $K_{v}$ channel in voltage-dependent activation. Nat Commun. 2020;11(1):676. http://dx.doi.org/10.1038/s41467020-14406-w. PMid:32015334.

Jamshidi-Kia F, Lorigooini Z, Amini-Khoei H. Medicinal plants: past history and future perspective. J Herbmed Pharmacol. 2018;7(1):1-7. http://dx.doi.org/10.15171/jhp.2018.01.

Jenkinson DH, Barnard EA, Hoyer D, Humphrey PP, Leff P, Shankley NP. International union of pharmacology committee on receptor nomenclature and drug classification. IX. Recommendations on terms and symbols in quantitative pharmacology. Pharmacol Rev. 1995;47(2):255-66. PMid:7568328. 
Kim HR, Appel S, Vetterkind S, Gangopadhyay SS, Morgan KG. Smooth muscle signalling pathways in health and disease. J Cell Mol Med. 2008;12(6A):2165-80. http://dx.doi.org/10.1111/j.15824934.2008.00552.x. PMid:19120701.

Kumar M, John M, Madhavan M, James J, Omkumar RV. Alteration in the phosphorylation status of NMDA receptor GluN2B subunit by activation of both NMDA receptor and L-type voltage gated calcium channel. Neurosci Lett. 2019;709:134343. http://dx.doi.org/10.1016/j.neulet.2019.134343. PMid:31279915.

Kyriacou MC, El-Nakhel C, Graziani G, Pannico A, Soteriou GA, Giordano M, Ritieni A, De Pascale S, Rouphael Y. Functional quality in novel food sources: genotypic variation in the nutritive and phytochemical composition of thirteen microgreens species. Food Chem. 2019;277:107-18. http://dx.doi.org/10.1016/j.foodchem.2018.10.098. PMid:30502125.

Long SB, Campbell EB, Mackinnon R. Voltage sensor of Kv1. 2: structural basis of electromechanical coupling. Science. 2005;309(5736):903-8. http://dx.doi.org/10.1126/science.1116270. PMid:16002579.

Melchiorre C, Angeli P, Lambrecht G, Mutschler E, Picchio MT, Wess J. Antimuscarinic action of methoctramine, a new cardioselective $\mathrm{M}-2$ muscarinic receptor antagonist, alone and in combination with atropine and gallamine. Eur J Pharmacol. 1987;144(2):117-24. http://dx.doi.org/10.1016/0014-2999(87)90509-7. PMid:3436364.

Mehmood MH, Munir S, Khalid UA, Asrar M, Gilani AH. Antidiarrhoeal, antisecretory and antispasmodic activities of Matricaria chamomilla are mediated predominantly through $\mathrm{K}^{+}$-channels activation. BMC Complement Altern Med. 2015;15(1):75. http://dx.doi.org/10.1186/s12906-015-0595-6. PMid:25886126.

Monteiro FS, Carvalho AFS, Marques EC, Ribeiro RM, Borges ACR, Borges MOR. Antidiarrhoeal and antispasmodic activity of leaves of Syzygium cumini L. Myrtaceae) mediated through calcium channel blockage. Afr J Pharm Pharmacol. 2018;(1):11-8. http://dx.doi.org/10.5897/AJPP2017.4868.

Monteiro FS, Carvalho AFS, Ribeiro RM, Borges ACR, Borges MOR. Phytochemical profile and investigation of the spasmolytic activity of hydroalcoholic extract of Syzygium cumini (L.) Skeels Seeds. European J Med Plants. 2020;(3):27-38. http://dx.doi.org/10.9734/ejmp/2020/v31i330220.

Montgomery LE, Tansey EA, Johnson CD, Roe SM, Quinn JG. Autonomic modification of intestinal smooth muscle contractility. Adv Physiol Educ. 2016;40(1):104-9. http://dx.doi.org/10.1152/advan.00038.2015. PMid:26873897.

Murthy KS. Signaling for contraction and relaxation in smooth muscle of the gut. Annu Rev Physiol. 2006;68(1):345-74. http://dx.doi.org/10.1146/annurev.physiol.68.040504.094707. PMid:16460276.

Oteiza PI, Fraga CG, Mills DA, Taft DH. Flavonoids and the gastrointestinal tract: local and systemic effects. Mol Aspects Med. 2018;61:41-9. http://dx.doi.org/10.1016/j.mam.2018.01.001. PMid:29317252.

Patel K, Patel DK. Medicinal importance, pharmacological activities, and analytical aspects of hispidulin: A concise report. J Tradit Complement Med. 2017;7(3):360-6. http://dx.doi.org/10.1016/j.jtcme.2016.11.003. PMid:28725632.

Ratz PH, Berg KM, Urban NH, Miner AS. Regulation of smooth muscle calcium sensitivity: $\mathrm{KCl}$ as a calcium-sensitizing stimulus. Am J Physiol Cell Physiol. 2005;288(4):C769-83. http://dx.doi.org/10.1152/ajpcell.00529.2004. PMid:15761211.

Resende FA, Nogueira CH, Espanha LG, Boldrin PK, Oliveira-Höhne AP, Santoro de Camargo M, Quintino da Rocha C, Vilegas W, Varanda EA. In vitro toxicological assessment of Arrabidaea brachypoda (DC.) Bureau: mutagenicity and estrogenicity studies. Regul Toxicol Pharmacol. 2017;90:29-35. http://dx.doi.org/10.1016/j.yrtph.2017.08.010. PMid:28823851.

Rocha CQ, Queiroz EF, Meira CS, Moreira DR, Soares MB, Marcourt L, Vilegas W, Wolfender JL. Dimeric flavonoids from Arrabidaea brachypoda and assessment of their anti-Trypanosoma cruzi activity. J Nat Prod. 2014;77(6):1345-50. http://dx.doi.org/10.1021/np401060j. PMid:24871307.

Rocha CQ, Vilela FC, Cavalcante GP, Santa-Cecília FV, Santos-e-Silva L, dos Santos MH, Giusti-Paiva A. Anti-inflammatory and antinociceptive effects of Arrabidaea brachypoda (DC.) Bureau roots. J Ethnopharmacol. 2011;133(2):396-401. http://dx.doi.org/10.1016/j.jep.2010.10.009. PMid:20950679. 
Rodrigues VP, Rocha CQD, Périco LL, Santos RCD, Ohara R, Nishijima CM, Ferreira Queiroz E, Wolfender JL, Rocha LRMD, Santos ARS, Vilegas W, Hiruma-Lima CA. Involvement of opioid system, TRPM8, and ASIC receptors in antinociceptive effect of Arrabidaea brachypoda (DC) bureau. Int J Mol Sci. 2017;18(11):2304. http://dx.doi.org/10.3390/ijms18112304. PMid:29099043.

Sadraei H, Ghanadian M, Asghari G, Sekhavati N. Antispasmodic activity of apigenin and luteolin, two components of Dracocephalum kotschyi extract, on rat ileum contractions. J Herbmed Pharmacol. 2018;7(2):100. http://dx.doi.org/10.15171/jhp.2018.17.

Sakamoto T, Unno T, Kitazawa T, Taneike T, Yamada M, Wess J, Nishimura M, Komori S. Three distinct muscarinic signalling pathways for cationic channel activation in mouse gut smooth muscle cells. J Physiol. 2007;582(1):41-61. http://dx.doi.org/10.1113/jphysiol.2007.133165. PMid:17463038.

Serpeloni JM, Specian AFL, Ribeiro DL, Benício LM, Nunes HL, Franchi LP, Rocha CQ, Vilegas W, Varanda EA, Cólus I. Fridericia platyphylla (Cham.) LG Lohmann root extract exerts cytotoxic and antiproliferative effects on gastric tumor cells and downregulates BCL-XL, BIRC5, and MET genes. Hum Exp Toxicol. 2020;39(3):338-54. http://dx.doi.org/10.1177/0960327119888261. PMid:31726875.

Siraichi JTG, Felipe DF, Brambilla LZS, Gatto MJ, Terra VA, Cecchini AL, Cortez LE, Rodrigues-Filho E, Cortez DA. Antioxidant capacity of the leaf extract obtained from Arrabidaea chica cultivated in Southern Brazil. PLoS One. 2013;e72733(8):e72733. http://dx.doi.org/10.1371/journal.pone.0072733. PMid:24009700.

Shakya AK. Medicinal plants: future source of new drugs. Int J Herb Med [Internet]. 2016 Jun [cited 2020 June 07];4(4): 59-64. Available from: http://www.florajournal.com/archives/2016/vol4issue4/PartA/4-2-13-120.pdf

Souza ADZ, Heinen HM, Amestoy SC, Mendieta MC, Piriz MA, Heck RM. O processo de trabalho dos enfermeiros da atenção primária e a Política Nacional de Plantas Medicinais/Fitoterápicos. Rev Bras Plantas Med. 2016;18(2): 480-87. https://doi.org/10.1590/1983-084X/15_176.

Suguro M, Matsuyama H, Tanahashi Y, Unno T, Kitazawa T, Yamada M, Komori S. Muscarinic receptor subtypes mediating $\mathrm{Ca}^{2+}$ sensitization of intestinal smooth muscle contraction: studies with receptor knockout mice. J Vet Med Sci. 2010;72(4):443-51. http://dx.doi.org/10.1292/jvms.09-0458. PMid:20009428.

Sweeney HL, Hammers DW. Muscle contraction. Cold Spring Harb Perspect Biol. 2018;10(2):a023200. http://dx.doi.org/10.1101/cshperspect.a023200. PMid:29419405.

Takemura OS, linuma M, Tosa H, Miguel OG, Moreira EA, Nozawa Y. A flavone from leaves of Arrabidaea chica f. cuprea. Phytochemistry. 1995;38(5):1299-300. http://dx.doi.org/10.1016/00319422(94)00786-S.

Thorneloe KS, Nelson MT. Ion channels in smooth muscle: regulators of intracellular calcium and contractility. Can J Physiol Pharmacol. 2005;83(3):215-42. http://dx.doi.org/10.1139/y05-016. PMid:15870837.

Udia PM, Braide VB, Owu DU. Antispasmodic and spasmolytic effects of methanolic extract from seeds of Garcinia kola on isolated rat small intestine. Niger J Physiol Sci. 2009;24(2):111-6. http://dx.doi.org/10.4314/njps.v24i2.52912. PMid:20234749.

van Breemen C, Saida K. Cellular mechanisms regulating $\left[\mathrm{Ca}^{2+}\right]_{i}$ smooth muscle. Annu Rev Physiol. 1989;51(1):315-29. http://dx.doi.org/10.1146/annurev.ph.51.030189.001531. PMid:2653185.

Van Rossum JM. Cumulative dose-response curves. II. Technique for the making of dose-response curves in isolated organs and the evaluation of drug parameters. Int Pharmacodyn Ther. 1963;143:299-330.

Vissiennon C, Goos KH, Arnhold J, Nieber K. Mechanisms on spasmolytic and anti-inflammatory effects of a herbal medicinal product consisting of myrrh, chamomile flower, and coffee charcoal. Wien Med Wochenschr. 2017;167(7-8):169-76. http://dx.doi.org/10.1007/s10354-016-0538-y. PMid:28091973.

Webb RC. Smooth muscle contraction and relaxation. Adv Physiol Educ. 2003;27(4):201-6. http://dx.doi.org/10.1152/advances.2003.27.4.201. PMid:14627618.

Qin X, Liu S, Lu Q, Zhang M, Jiang X, Hu S, Li J, Zhang C, Gao J, Zhu MS, Feil R, Li H, Chen M, Weinstein LS, Zhang $Y$, Zhang W. Heterotrimeric $G$ stimulatory protein a subunit is required for intestinal smooth 
muscle contraction in mice. Gastroenterology. 2017;152(5):1114-25.

http://dx.doi.org/10.1053/j.gastro.2016.12.017. PMid:28043906.

Yanagizawa YA, Maimoni-Rodella, RDCS. Floral visitors and reproductive strategies in five melittophilous species of Bignoniaceae in Southeastern Brazil. Braz Arch Biol Technol. 2007;50(6):1043. https://doi.org/10.1590/S1516-89132007000700015.

Author contributions: FSM: conceptualization, data curation, formal analysis, investigation, methodology, project administration, supervision, visualization, writing - original draft; JRSC: conceptualization, data curation, formal analysis, investigation, validation, visualization, writing original draft; LJAM: data curation, formal analysis, investigation, validation; CQR: conceptualization, data curation, formal analysis, investigation, methodology, project administration, supervision, visualization, writing - original draft; ACRB and MORB: conceptualization, resources, writing - review \& editing. 